\title{
ДВЕ ЦЕРКОВНОСЛАВЯНСКИЕ ФОРМУЛЫ В МИФОЛОГИИ УКРАИНСКОГО ЗАКАРПАТЬЯ
}

1. Первая из формул, о которых идет речь, широко известна в восточно- и западнославянском мире. Это цитата из 150-го псалма: «Всякое дыхание да хвалит Господа». Она широко распростанена в Закарпатье и вообще в Карпатском регионе как отгонная формула и оберег при встрече с нечистой силой (см., например, Черленяк 2018: 664). Ср. запись из закарпатского села Керецки Иршавского р-на:

И водяникы́ - слу́чайі такі́, розумі́ете, ка́же, водяни́к иде́, водо́в иде́ та 3 ро́та му са́пать. По́ловинь[ий]. По́ловинь, ка́же, така́ черле́на 3 ро́та му са́пать. Я́ самá - мы́ коло ріки́ жи́еме, та.. уже́ типи́рь ньи́т, а да́вно, десь прибли́зно в восӥмдися́т тре́тьому ро́ці [...] вы́шла ся́к на фе́рму у ночи́. Про́сто мині́... мині́ ві́діло ся, шо то́ чоти́ри го́дины, по мі́сному, а вто́ бы́ло двана́ццить го́дин тогды́. Стрі́лка бы́ла мала́ на дванацитьо́х, а мні́ ся пові́діло, шо стрі́лка на чотырьо́х го́динах, мала́. Но та я́ поміша́ла. Коли́-м ишла́ на фе́рму, позира́у, горі́ водо́в та́к собí йде́, тако́е сьві́тло, серед.. посеред саме́нькоі рікы́. Но́ а то давно́ шче́ бйльше бы́ло тако́го. Типи́рь уже ма́ло... (А что нужно было сделать, перекреститься?) Перехрести́ти ся тре́ба та казати, ош «Вся́кое дыха́ние да хвали́ть Го́спода». Отаку́ рі́ч бы́ло тре́ба произнести́.

[И водяники - случаи такие, понимаете, говорят, водяник идет, идет по воде, и изо рта у него пышет. Пламенем. Пламя, говорят, такое красное изо рта у него пышет. Я сама - мы около реки живем, и... уже теперь нет, а давно, где-то приблизительно в восемьдесят третьем году, я вышла так на ферму ночью. Просто мне... мне казалось, что это четыре часа, по-местному, а это было двенадцать часов тогда. Стрелка была маленькая на двенадцати, а мне показалось, что стрелка на четырех часах, маленькая. Ну и я перепутала. Когда я шла на ферму, смотрю, вверх по реке так идет такой свет, посреди.. посреди самой реки. Ну а давно еще

DOI: $10.31168 / 91674-564-1.17$ 
больше было такого. Теперь уже мало. - Нужно перекреститься и сказать, что «Всякое дыхание да хвалит Господа». Вот такую вещь нужно было произнести] (КА, аудиозапись Е.В. Степановой (Лесиной), 1990 г.).

Ту же функцию имеет эта формула в эпизоде из книги о сельской жизни закарпатского писателя, уроженца с. Осой Иршавского р-на Ивана Петровция:

Май бӥлше чомусь тото ничистоє ся имало до Гафії. Сперву якось увичирї нафараллована деннов роботов сидїла собі на стӥльчику пиля шпора, та ся гріла. Кой туй штось лампу задуло, и такый нараз сїло йӥв на руку, онь рука гибы задиривіла - ани кынути нив. Дале задирівыв и язык хотїла гойкнути, когось покликати - язык ся ани кывать... Розсердила ся - хотїла плюнути на тото чорноє, што ї прислопанило, айбо ни годна была удручати языком из рота слину - лем по бородї йӥв потекла.

У мыслях ся помолила:

- Всякоє дыханіє да хвалит Господа! А ты ци хвалиш!?.

Запищало дїтинськым голоском, дале - жӥнськым, и - удпустило, лем у сїнні двирї загримотїло... Пӥшло гет!

[Больше всего это нечистое почему-то цеплялось к Гафии. Сначала как-то вечером, утомленная дневной работой, она сидела себе на табуреточке около печки и грелась. Как вдруг что-то задуло лампу, и так сразу село ей на руку, аж рука как будто одеревенела - невозможно ею двинуть. Потом одеревенел и язык - хотела крикнуть, кого-нибудь позвать - язык не двигается... Рассердилась - хотела плюнуть на это черное, что ее придавило, но не могла вытолкнуть языком изо рта слюну - только потекла у нее по подбородку.

Мысленно она помолилась:

- Всякое дыхание да хвалит Господа! А ты хвалишь?!

Запищало детским голосом, потом - женским, и - отпустило, только загремело дверями в сенях... Ушло!] (Петровцій 2014).

Характерно, что об этом выражении здесь говорится «помолиться». В таком употреблении оно стоит в ряду других молитвенных формулоберегов: «Помилуй ня Боже» [Толстая 2001: 480], «Слава Ісусу Христу» (Гнатюк Е3 33: 97, № 242), «Сьват-сьват-сьват Матьінко Божа» (Гнатюк Е3 15: 157, № 262), «Мне оца і сина і сьвитого...» (Гнатюк ЕЗ 15: 47, № 86) и т. п.

Однако данная формула имеет и более специализированное употребление, которое можно охарактеризовать как функцию распознавания, «пароля» при контакте с неведомым (чаще всего с ходячим покойником или душой), связанную с представлениями о «чистых» и «нечистых» 
душах из загробного мира и так называемых «покутниках» - неприкаянных душах, по разным причинам не находящих упокоения в загробном мире (из-за незавершенных земных дел, грехов и др.) и ищущих помощи от живых; комплекс восточнославянских представлений о «покутниках» подробно рассмотрен в специальной статье Л.Н. Виноградовой (Виноградова 2019). В ответ на «Всякое дыхание да хвалит Господа» «чистая» душа отзовется: «И я хвалю» и объяснит, в чем она нуждается, а нечистая промолчит или отругнется и исчезнет. Это объяснение неоднократно встречается в этнографической литературе и полевых записях; в частности, из того же с. Керецки Иршавского р-на':

Чолові́к кедь да́шчо хо́че, котры́й умре́, та кедь да́шчо хо́че, пожа́дать та́м шчо́сь кому́сь до́вжен да́шчо, ци да́шчось и́нше пожа́дать, - та тогды́ вй́н ся з'я́вить люди́ні якось, чолові́ку ци жоні́. Но та тре́ба, кому́ ся з’яви́ть - та тре́ба його́ спроси́ти. Тре́ба каза́ти «Вся́кое дыха́ние да хвали́ть Го́спода». А вно́ ни пові́сть на́раз. А до дру́гий ра́з испроси́ти. А вно́ ка́же за́сь - «И я́ хвалю́». Та кедь ка́же, ош «И я́ хвалю́»- тогды́ тре́ба зьві́довати, ош «Пак шчо́ ты хо́чеш?». А вно́ вже тогды́ ка́же, ош шчо́ йому́ тре́ба. Ци вно́ кому́сь гро́ші до́вжно, ци вно́ кому́ да́шчось.. зло́й ді́ло зроби́в, та тре́ба му заплати́ти. Та́к шо тогды́ я́к овйн сво́й вы́повісьць, тогды́ вӥн уже́ пак ни́гда ся ни я́влять.

[Человек когда что-то хочет, который умер, и когда что-то хочет, нуждается в чем-то - там что-то кому-то должен, или в чем-то ином нуждается, - то тогда он является какому-нибудь человеку, мужчине или женщине. И надо, кому он явится - надо его спросить. Надо сказать: «Всякое дыхание да хвалит Господа». А оно сразу не ответит. А еще раз спросить. А оно тогда говорит - «И я хвалю». И когда скажет «И я хвалю», - тогда нужно спрашивать: «Так что ты хочешь?» А оно тогда уже говорит, что ему нужно. Или оно кому-то должно деньги, или оно кому-то что-то... злое дело сделал, и надо ему заплатить. Так что тогда, как он свое выскажет, тогда уже он потом никогда не является] (КА, аудиозапись Е.В. Степановой (Лесиной), 1990 г.).

Характерно, что о произнесении этой формулы часто говорится «спрашивать» (ср. Гнатюк Е3 34: 67, № 722), хотя лишь в отдельных случаях

Диалектные тексты из Карпатского архива (КА) приводятся в упрощенной записи. Используются следующие условные обозначения: [...] означает пропуск в записи или в расшифровке, .. - «естественную» паузу в речи; диалектный текст в квадратных скобках - не вполне ясные отрезки речи. В угловые скобки заключены пояснения. Знаки препинания отражают фразовую интонацию и синтаксическое членение текста. 
к ней прибавляется вопрос типа «А ты хвалишь?». Например, в полевой записи из Прикарпатья (с. Печенежин, окрестности Коломыи):

Ну як помре́ хтось такий шо ше с то́го сьві́та шо жида́йи сво́їх рі́дних, ну́ то прихо́дит душа́ поку́туйи. Ну́ як прихо́дит лу́скайи шос у ха́ті, то тре́ба запита́тись: «Вся́ке диха́нні да хва́лит Го́спода», як шо чи́ста душа́, то ска́же «Тай я́ хвалю́», тогди́ як она́ ска́же «Тай я́ хвалю́», тогди тре́ба запита́тиси, «Шо душє́ потрібу́є». То душе́ відповіда́йи, кі́лько службі́у Бо́жих найми́ти, і кі́лько молитві́в змоли́ти, а́бо мо́же шо́сь купи́ти и за прости́біг да́ти. Та́к, і тогди́ вже.. а якшо́ ничи́ста душа́, то тогди́ моўчи́т, то тогди́ тре́ба ду́же бога́то моли́тси, би це ўтступи́лоси с ха́ти, би це́.. аби це́ не лу́скало тей не му́чило ци́х живи́х, шо ше жи́ют у цій ха́ті.

[Ну если умрет кто-то такой, что с того света нуждается в помощи своих родных, то приходит душа покутует. Ну если приходит и стучит что-то в хате, то нужно спросить: «Всякое дыхание да хвалит Господа», и если чистая душа, то скажет: «И я хвалю»; тогда, как она скажет: «И я хвалю», - тогда надо спросить: «В чем душа нуждается?» И душа отвечает, сколько служб Божьих заказать, и сколько молитв измолить, или, может, что-то купить и дать «за простибіг» (бедным). А если нечистая душа, то тогда молчит, то тогда нужно очень много молиться, чтобы это отступилось от хаты, чтобы это не стучало и не мучило тех живых, что еще живут в этой хате] (КА, аудиозапись Е.Л. Рязанской и М.Н. Толстой, 1990 г.).

Это же объяснение записано и в с. Синевир Межгорского р-на в заключение былички о том, как умершая тетка несколько раз являлась маленькой девочке. Отец научил ее, что надо сказать «Всякое дыхание да хвалит Господа», но девочка от страха не могла это вымолвить. Покойница, явившись в очередной раз, схватила девочку за пятку, и та не сказала, но мысленно произнесла эту фразу. Тетка ответила: «И я хвалю. Не мучь меня столько, а иди скажи дяде, что я запрятала там-то и там-то деньги, хотела дать на три службы, но не успела; пусть добавят денег и дадут на три службы, и вы меня больше никогда не увидите». Так и было сделано (см. полный текст в Толстая 1999: 488-490):

То ния́кый ни чо́рт, ай тото́ зна́єте, тото́ ка́жут шчо тото́.. ишче́ душа́ шчо́сь нароби́ла недо́брого вся́кого, зла́, но́ та она́ шче на тй́лько у Бо́га у́просила ся, шчобы́ йі Бо́г пусти́в, йийі́ ду́х обы́ пусти́в, обы́ она́ попроси́ла вӥт си́х, роди́ны вӥт се́йі, яку́сь по́мӥч. Но́ тай ка́же шо.. ка́жут, ся́к говори́т: «Вся́коє дыха́ниє да хва́лит Го́спода», - и она́ тогды́ ка́же, тота́ душа́, а котра́ нечи́ста, тота́ ни вӥтпові́сць вам. Тота́ ни вӥтпові́сць ния́к. Но́. 
[Это никакой не черт, а это знаете, это говорят, что это.. еще душа чтото наделала нехорошего всякого, зла, ну и она еще на столько у Бога выпросилась, чтобы ее Бог пустил, ее дух чтобы пустил, чтобы она попросила у этих, у своих родных, какую-то помощь. Ну и говорят, что.. говорят, так говорят: «Всякое дыхание да хвалит Господа», - и она тогда скажет, эта душа, а которая нечистая, та не ответит вам. Та не ответит никак] (КА, аудиозапись Е.В. Степановой (Лесиной), 1993).

Ср. то же в материалах из Староконстантиновского уезда Волынской губ. (ныне Хмельницкая обл.) у И. Беньковского:

По верованию нашего народа, бывает, что иногда добрый, а иногда злой дух принимает вид или облик известного покойника, или вселяется в «тулубец», в тело известного покойника, и по ночам ходит; для того чтобы знать, какой дух это, добрый или злой, - при встрече с ним - нужно спросить: «Во имя Отца Сына и Свят. Духа. Всяка тварь хвалыть Бога, а ты хвалыш?» Если то добрый дух, то скажет «хвалю», будет говорить и скажет, что ему, т. е. ей - душе - нужно, а если то злой дух, то на подобное приветствие или вопрос будет молчать и ничего не ответит, а если его перекрестить или читать «Да воскреснет Бог», то злой дух в образе умершего человека сейчас «счезне» (Беньковский 1896: 30).

Еще один пример «покуты» (посмертного наказания за грех) и просьбы покойника о помощи записан в с. Черный Поток Иршавского p-на Закарпатья:

Но пак прихо́дить <покойник>.. но пак зьві́давуть го, ош шчо́. (А як він приходить?) Люди́нов про́сто. Но пак иде́ та́к, я́к його́ покла́ли, та́к овйн иде́. [...] А иде́ чолові́к сякы́̆ <живой>, но та сякы́й як ви́дить мертво́го, та ка́же «Вся́коє дыха́ниє да́ хвали́ть Го́спода», а мертвы́й ка́же «И я́ хвалю́». [...] Но каза́ли ня́нько, проще́ний бы́в, ош чолові́к уме́р, а ходи́в. Но́ та... я́ ни зна́ву, ци вни́ йшли́, ци кось дру́гый, - та ка́же «Вся́коє дыха́ниє да́ хвали́ть Го́спода», а вто́ ка́же «И я́ хвалю́». - «Но та шчо́ хо́диш, шчо́ ти тре́ба?» - «Пові́жте, - ка́же, - на́шим - я́ не ма́ву та́м сопоко́ю. Бо фу́рт у мня ся, - ка́е, - ды́ня ка́чать долӥ бе́регом, а я́ ни го́ден ими́ти, та не ма́ву сопоко́ю, е́, на тй́м сьві́ті». Ды́ня, но ды́ня. А вй́н укра́в ды́ню д ко́гось. Овйн укра́в ды́ню, укра́в, а та́м ся перед ни́м зь'яви́ла. Та ды́ня ся фу́рт кача́ла долӥ бе́регом, а вй́н не [...] го́ден ими́ти ды́ню, бо ды́ня долӥ бе́регом, та вті́кать, та не мо́ж ими́ти. Та не ма́в сопоко́ю. [...] «Пові́жте, ка́же, на́шым, обы́ дали́ то́му и то́му ды́ні». [...] Но́ та пак пові́ли, ош «Да́йте то́му ды́ню», но та 
да́ли то́му ды́ню, пото́му ни ходи́в. $<$ Он> ни босорку́н бы́в, вӥн про́сто вкра́в. Кра́сти не мо́ж, не сло́бӥдно кра́сти, про́сто вкра́в.

[Ну приходит <покойник>.. ну и спрашивают его, в чем дело. (А как он приходит?) Человеком просто. Ну идет так, как его положили <в гроб>, так он идет. А идет мужчина такой <живой>, ну и такой, когда видит мертвого, говорит: «Всякое дыхание да хвалит Господа», - а мертвый говорит: «И я хвалю». Ну говорил папа, царствие ему небесное, что один мужчина умер и ходил. Ну и... я не знаю, отец шел или кто-то другой, - и говорит: «Всякое дыхание да хвалит Господа», а это отвечает: «И я хвалю». - «Так что ты ходишь, что тебе нужно?» - «Скажите, - говорит, - нашим - нет мне там покоя. Потому что все время у меня, - говорит, - тыква катится вниз по склону, а я не могу поймать, и нет мне покоя на том свете». Тыква, ну тыква. А он украл тыкву у кого-то. Он украл тыкву, украл, а там она явилась перед ним. И тыква всё время катилась вниз, а он не может поймать тыкву, потому что тыква катится вниз и убегает, и невозможно поймать. И не было ему покоя. «Скажите, - говорит, - нашим, чтобы дали тому-то и тому-то тыкву». Ну и сказали, что «Дайте тому тыкву», и дали тому тыкву, потом <покойник> не ходил. Он был не босоркун, он просто украл. Красть нельзя, запрещается красть, просто украл] (КА, аудиозапись С.П. Бушкевич, 1993 г.).

Мини-диалог «Всякое дыхание да хвалит Господа» - «И я хвалю», как бы «пароль» и «отзыв» на него, многократно зафиксирован в этнографической литературе, относящейся к юго-западу Украины (Гнатюк Е3 15: 146-147, № 246; Е3 34: 46, № 662, 49, № 668; Е3 31-32: 377; Чуб.ТЭСЭ 1: 148-149; НДП 2: 371; ГПЗН: 15). Среди карпатских диалектных текстов, опубликованных И. Панькевичем, есть длинная быличка из закарпатского села Ольховцы о том, как нечистая сила мучила чабанов на полонине. Их колиба (сезонное жилище) стояла там, где до этого была зверски убита молодая девушка-пастушка; по ночам к ним приходили ведьмы, черти и души-«покутники», а однажды пришла красивая девушка, и именно к ней они обратились со словами «Всякое дыхание да хвалит Господа» ${ }^{2}$ :

Но и та́к звари́ли вни вече́рю і повече́ряли і прихо́дит одна́ ді́вка ду́же пре́си́лно кра́сна і сі́ла она іс пе́рек на́кладя і не могли́ ся надиви́ти на ту ді́вку і каза́ли йуй: уся́кує дыха́ніє да хвали́т Го́спода. Каза́ла вна́: і я да хвалю́. За́чали йі зві́довати: шчо жу́риш ді́вко, шчо сюды́ 
хо́диш, шчось сюды́ заблуди́ла. Она́ ка́же: я туй скота́рила и прийшо́в оде́н уча́рь і мене́ рошча́х і пові́сив мене́ на коли́бі, бо я 3 ни́м не хо́тіла полюби́ти ся приста́ти, як вун мені́ каза́в. Но і так тота́ ді́вка наговори́ла ся з ни́ми и пушла́ собі́, лиш ві́тер заві́яв. I чу́ют они́ тоты́ лю́ди а ді́вка так ду́же за́чала йо́йкати тонкы́м го́лосом. I пушла́ вна на тото́ мі́сто, де йійі́ вуча́рь тот рошча́х. I так они́ ся ду́же боя́ли <..> [Ну и так сварили они ужин и поужинали, и приходит одна девушка, очень-очень красивая, и села она перед накладом <колода, заслоняющая огонь костра со стороны колибы>, и не могли налюбоваться на эту девушку, и сказали ей: «Всякое дыхание да хвалит Господа». Сказала она: «И я да хвалю». Начали ее спрашивать: «Что печалишься, девушка, что сюда ходишь, что ты сюда забрела?» Она говорит: «Я здесь пасла скот, и пришел один чабан и меня растерзал, и повесил меня на колибе, потому что я не хотела согласиться с ним полюбиться, как он от меня требовал». Ну и так эта девушка наговорилась с ними и пошла себе, только ветер поднялся. И слышат эти люди, а девушка так начала плакать очень тонким голосом. И пошла она на то место, где ее чабан тот растерзал. И так они очень боялись <...>] (Панькевич 1938: 432-435).

Встречается этот мини-диалог и в рассказе Ивана Франко «Як русин товкся по тім світі» (Франко 1978):

- Гей, хто там? - кричав Русин, нахилившися над кітлом, у якім кипіла-клекотіла смола. - Всякоє диханіє да хвалить господа! Чуєте там? Озивайтеся.

- I ми хвалимо! I ми хвалимо! - пискотіло щось із глибини.

- Випливайте наверх, бідні душі! - крикнув Русин, але душі не випливали, тілько все пискотіли.

- Господи, змилуйся! Господи, змилуйся!

Из текста И. Франко видно, что «Всякое дыхание...» употребляется и просто как приветствие в адрес душ из загробного мира. Так же эта формула используется и в диалектном тексте о двоедушнике, летавшем на шабаш ведьм, из с. Белки Иршавского р-на (УЗГТ: 89-90), который заслуживает того, чтобы привести его полностью ${ }^{3}$ :

\section{Про Івана-дводушника}

Быв у нас у селі́ йеде́н Ива́н, ни зна́ву, як ся писа́в. Мы бы́ли малі́, кой колхо́з ся заснува́в. Мы попа́сували коро́вы 3 ціло́го села́, бо волы́ 
гна́ли в полони́ну. Ива́на пужа́ли, ош колхо́з уд ньо́го зи́млю забе́ре. Овй́н зазьві́дав, ош тко колхо́з заснува́в, а да́ле поча́в на то́го чолові́ка по́стити, тай тот чолові́к уме́р. Каза́ли, ош овйн двоєду́шник. Уди́нь вӥн до́бре не ві́дів, а ги кой черес сы́то. Коро́ву держа́в усе́ за мо́туз, бо йі не ві́дів. Уночи́ хло́пці го все перегово́рювали, обы не йшо́в из ты́ми сво́йіми, а лиша́вся 3 ни́ма. А Ива́н каза́в, што вӥн не го́ден, бо бу́де в них мани́бря. Ра́но го зьві́дали, ош де́ быв. Овй́н роска́зовав, ош мани́бря бы́ло на румы́нськӥй грани́ци, тай каза́в, ош на Укра́йіні $є$ шчи май ста́ршый за ньо́го. Коли́ вӥн ішо́в рас на во́ду, та ві́дів мно́го душ, та каза́в йім: «Вся́коє дыха́ниє да хвали́ть Го́спода Бо́га», - а ду́ші му каза́ли, ош іду́ть на ту гору́, де Христа́ роспина́ли. Дале ви́дить, што йде ци лити́т єдна́ душа́. Вклони́вся йӥй тай зазьві́дав, де вна йде. Она́ му росказа́ла, ош кой бы́ла хво́ра, та пообіця́ла на слу́жбу, а не да́ла, бо вме́рла, и тепе́рь она му́сить ка́ждый рӥк прине́сти из обша́ря знак вать коро́ва здо́хне, вать діти́на умре́; і вна́ проси́ла Ива́на, обы́ вӥн ийсе́ впові́в йійі́ доньці́, обы́ вта да́ла на слу́жбу, яку́ ба́ба пообіця́ла попо́ви. I товды́ в них і ді́ти триє́ были. Ива́н сесь быв ду́же ле́павый, ни́гда ся не мыв тай не бры́твав. Тай каза́в, ош як умре́, та обы́ го не не́сли через дви́рі́, ай через во́зӥр. Та так и бы́ло, бо брат му в сьтіні́ ýрубав во́зӥр та через ото́ го у́несли.

\section{[Про Ивана-двоедушника}

Был у нас в селе один Иван, не знаю, как по фамилии. Мы были маленькие, когда был основан колхоз. Мы пасли коров с целого села, потому что волов гнали на полонину. Ивана пугали, что колхоз заберет у него землю. Он спросил, кто основал колхоз, а потом начал на того человека поститься <т. е. держать пост с целью его извести>, и тот человек умер. Говорили, что он двоедушник. Днем он плохо видел, как через сито. Корову всё время держал за повод, потому что ее не видел. Ночью хлопцы всё его уговаривали, чтобы он не шел с теми своими, а оставался с ними. А Иван сказал, что не может, потому что у них будет манибря <«маневры»>. Утром его спросили, где он был. Он рассказывал, что манибря было на румынской границе, и сказал, что на Украине есть еще старший над ним. Когда он однажды шел по воду, увидел много душ, и сказал им: «Всякое дыхание да хвалит Господа Бога», - а души ему сказали, что идут на ту гору, где распинали Христа. Потом видит, что идет или летит одна душа. Поздоровался с ней и спросил, куда она идет. Она ему рассказала, что когда была больна, то пообещала на службу <в церковь>, а не дала, потому что умерла, и теперь она должна каждый год принести из <своего> хозяйства знак - или корова сдохнет, или ребенок умрет; и она просила Ивана, чтобы он это рассказал ее дочери, чтобы та дала на службу, 
которую баба пообещала попу. И тогда у них и детей трое было. Иван этот был очень грязный, никогда не мылся и не брился. И сказал, что когда умрет, то чтобы его не несли через двери, а через окно. И так и было, брат его в стене прорубил окно и через это его вынесли].

Помимо известного мотива «ведьма вредит своим родным» (см. Виноградова 2016: 121-129), этот рассказ содержит и редкое свидетельство представлений о том, что вредить поневоле может и «чистая» душа, и в этом состоит ее «покута».

В нескольких сюжетах отмечается, что при общении с покойником формула должна быть произнесена трижды (или дважды - как в с. Керецки), прежде чем он ответит на нее (Гнатюк ЕЗ 33: 78, № 171; Гнатюк Е3 15: 145-146, № 246). Во Владимир-Волынском р-не Волынской обл. считалось, что живой человек трижды ответит «И я хвалю!», а покойник - лишь дважды (НДП 2: 371).

Вне сферы мифологии формула «Всякое дыхание да хвалит Господа» и ответ на нее могут употребляться в ситуациях, когда человек боится непонятного, - с той же функцией распознавания «своего», представителя «этого» мира:

(Кажут так - «Всякое дыхание да хвалит Господа»?) Ка́жут. Як ся бойи́ш.. як ся бойи́ш, йде́ш у ночи́ та шо́сь.. стра́шно, шо́сь-ись доди́вила та ни зна́єш, шо́ тото́, та тре́ба каза́ти, шо «Вся́коє дыха́ниє да хвали́т Го́спода». Но а тото́ аш иде́ тако́є, я́ вать ти́, - та ка́же «я́ да хвалю́». Та тогды́ зна́чит ни боя́тися, бо тото́ люди́на яка́сь иде́. Но а як ни́ч ни ка́же, то тогды́ я́ не зна́ю, верта́тися мо́же?

Но пак я́ бим ишла́ та де́сь-им тя уві́діла та ни познаю́ тя. Та яко́сьим ся напу́дила, бо мо́же стойи́ш, та не зна́ю, ци тото́ пе́нь, ци тото́ люди́на, ци тото́... мо́же... пе́с - «Вся́коє дыха́ниє да хвали́т Го́спода», я́ бим каза́ла. А ты́ бись учу́ла, шо я́ ся́к ка́жу, та обы́м я́ ся ни боя́ла, каза́ла бись - «И я́ да хвалю́».

Пак а е́ такі́ шо ни зна́йе, шо́ каза́ти, то ни ка́же ни́ч!

[(Говорят так - «Всякое дыхание да хвалит Господа»?) Говорят. Если боишься... если боишься, идешь ночью и что-то... страшно, что-нибудь ты увидела и не знаешь, что это, то нужно сказать, что «Всякое дыхание да хвалит Господа». Ну а это если идет такое, я или ты, - то говорит: «Я да хвалю». И тогда, значит, не бояться, потому что это человек какой-то идет. Ну а если ничего не говорит, то тогда я не знаю, может быть, возвращаться?

Ну вот я бы шла и где-то бы тебя увидела, и не узнаю тебя. И как-то я напугалась, потому что, может, ты стоишь, и я не знаю, то ли это пень, 
то ли человек, то ли... может... собака - «Всякое дыхание да хвалит Господа», я бы сказала. А ты бы услышала, что я так говорю, и чтобы я не боялась, ты бы сказала: «И я да хвалю». Ну а есть такие, что не знает, что надо сказать, и ничего не говорит!] (КА, с. Синевир Межгорского р-на Закарпатской обл., аудиозапись М.Н. Толстой, 2019 г.).

В трех быличках, опубликованных В. Гнатюком (Гнатюк Е3 33: 78, № 171; Е3 34: 22, № 614; Е3 15: 146-147, № 248), формула произносится по-польски; в двух из них действуют ксендзы, в третьей - «знающий» мазур. Это не случайно: фразеологизм Wszelki duch Pana Boga chwali! широко известен у поляков. По данным WSJP, он используется для выражения удивления или страха говорящего, известен и ответ на него I ja Go chwale. Формула отмечена и в польской мифологии: с ней обращались к душам некрещеных детей, летающим в ветре (еще одна разновидность неприкаянных душ) (Pełka 1987: 50); в легенде о поляне Centyrz в Западных Бескидах призрак монаха, сбежавшего из монастыря и убитого грабителями, перестал появляться после того, как эту формулу произнес испуганный им человек и он ответил на нее ${ }^{4}$, т. е. избавление монаху-«покутнику» принес уже сам этот диалог

Можно было бы предположить, что магическое употребление формулы «Всякое дыхание да хвалит Господа» под польским влиянием распространилось на бывших польских землях, однако этому противоречит, с одной стороны, видимое отсутствие ее следов на основной территории Полесья, в Белоруссии, а также и у гуцулов, а с другой стороны - распространенность ее в Закарпатье. Наконец, впечатляющая параллель обнаруживается у южных славян, где широко распространены представления о «ходячих покойниках»-вампирах, которых не принимает земля за их грехи, и они обречены определенное время ходить по земле (Ђорђевић 1953: 164-166). В быличке из Славонии парень, укравший у соседа соль и не признавшийся в этом перед смертью, стал вампиром; по совету селян родители раскопали его могилу и обнаружили его в гробу курящим трубку; они трижды его «заклинали»: «Свака душа фали Бога, фалиш ли га ти?» [Всякая душа хвалит Бога,

https://pl.wikipedia.org/wiki/Centyrz

5 Некоторой параллелью к этому сюжету может служить белорусская быличка из Гродненской губернии, в которой призрак монаха, при жизни никогда не произносившего «роchwalony» (традиционное приветствие «Niech będzie pochwalony Jezus Chrystus!» [Слава Иисусу Христу!]), был выручен от «покуты» ксендзом, обратившимся к нему с этим приветствием, на что призрак ответил: «Na wieki wieków amen!», затем поблагодарил и исчез (Fed. LB 1: 55). 
хвалишь ли его ты?], и на третий раз он ответил: «Фалим да! Ја ко и ви» [Хвалю, да! Я как и вы], после чего объяснил, что осужден на два года «ходить»; родители проткнули его тело колом боярышника, в результате чего проблема была решена:

У једној народној привовеци из Отока, у Славонији, казује се како кад «когод што украде мора на самртном часу очитовати укућанима да намире да не би он неспокојан посли долазио ноћу кући». О томе се даље овако прича: Неки младић чувајући говеда украде од суседа камен соли и даде својој говеди. Неко време после тога он умре, «не казавши то на самртном часу». «Седме ноћи чују укућани по кући страшну лупу, падају здиле и лонци, руше се котлови и чаброви, и нико не смије да виде што је». Неко заговори његове укућане «да плате Гргурске мисе, не би ли се зла ослободили», али је све било узалуд. Најзад им рекну сељани да «одсику гложић јединак, па нек иду у гробље». Они тако и учине, на гробљу «откопају раку, отворе шкрињу, а он лежи полеђице у шкрињи и пуши чубук». Родитељи га стану заклињати: «Свака душа фали Бога, фалиш ли га ти?» Тек на треће питање он одговори: «Фалим да! Ја ко и ви». - «Па зашто долазиш?» - «Е, вели, укро сам соли и реко миснику, а нисам вама, па да намирите. Зато ми је суђено да још дви године овако одам». Кад су родитељи чули у чему је ствар, «макну га глоговим коцем у три пут у затиљак; а кад је трећи пут добио, рукне он ко вол и издане. Он онда није више долазио» (Lovretić, Zborn. za nar. život, књ. VII, стр. 134).

[В одном народном рассказе из Отока в Славонии говорится, что, когда «кто-либо что-то украдет, он должен перед смертью признаться в этом домашним, чтобы у них было всё в порядке и он бы после не тревожил их, приходя ночью домой». Об этом дальше рассказывается так: Некий парень, пасший коров, украл у соседа кусок каменной соли и дал своим коровам. Через некоторое время он умер, «не сказавши этого перед смертью». «На седьмую ночь домашние услышали в доме страшный грохот, падают миски и горшки, двигаются котлы и кадки, и никто не решается посмотреть, в чем дело». Кто-то посоветовал его домашним «заплатить за Гргурске мисе <специальные заупокойные службы> - может быть, удастся освободиться от этого зла», но всё было напрасно. В конце концов односельчане сказали им, чтобы они «срезали однолетний прут (?) боярышника и шли на кладбище». Они так и сделали, на кладбище «раскопали могилу, открыли гроб, а он лежит на спине в гробу и курит трубку». Родители стали его заклинать: «Всякая душа хвалит Бога, хвалишь ли его ты?» Только на третий раз он ответил: «Хвалю, да! Я как и вы». - «Так зачем приходишь?» - «Э, - говорит, - я украл соль и сказал об этом священнику, а вам не сказал, чтобы у вас 
было всё в порядке. Поэтому мне суждено еще два года так ходить». Когда родители услышали, в чем дело, «ударили его боярышниковым колом трижды в затылок; когда ударили третий раз, он рыкнул, как вол, и испустил дух. И больше он не приходил»] (Ђорђевић 1953: 164-166).

2. Вторая формула, напротив, известна мне только из полевых записей в Закарпатье, и следов ее в литературе пока не удается найти. В Закарпатье во время экспедиций Института славяноведения в 1990-е гг. она записана по крайней мере четырежды, в трех селах и трех вариантах. Эти варианты таковы: иди́ со діло́м сво́им (дважды, Керецки Свалявск., 1990); най собі йде своіми суділа́ми (Черный Поток Иршавск., 1993); иди́ ис сво́йими суділіла́ми (Синевир Межгорск., 1993). Во всех случаях она обращена к мифологическим персонажам и имеет отгонную функцию в ситуациях, которые можно охарактеризовать как прекращение или отказ от общения; с некоторой натяжкой ее можно перевести как «Бог тебе судья». Ниже приводится полный материал.

\section{с. Керецки:}

Стары́й Костю́к быв прика́зовав, як його́ стри́й - то давно́ бы́ло - та йшо́в из лі́са, но пак ходи́в на орі́хы. Ув осени́ у на́с усе́, коли́ орі́хы ся уро́дять, та идеме́ на орі́хы. Та йшо́в, а на пути́ стои́т копи́чка орі́хӥв. Така́ копи́чка, шо йедны́м изве́рьхы заверше́на. А вй́н оть́ орі́хы забра́в у тайстри́нку, та пӥшо́в домú́. Тай ра́с у ночи́ слу́хать - а ся пуд вы́зором го́йкать. «Вы́ткысь оты́ орі́хы взя́в, та́м их и покла́дь, а кедь нье́т, - ка́же, - та та́к тя буду́ гони́ти, ги Мари́ю Катуно́ву». Тото́ в на́с ту́й бы́ли, та́к ся кли́кали. Та нидо́бре бы́ло жоні́. Но та та́к овйн пові́в йому́, росказа́в, ош та́к буде́ гони́ти, ги ту́. А се́сь пак изра́на уста́в, та красно́ тоты́ орі́хы, та́кой у ньо́го у тайстри́ні окре́ме и бы́ли, та поні́с на тото́ мі́сто, и та́м вй̈н уже́ йих ни скла́довав, бо вйн бы йих ни́гда та́к ни скла́в, ги вни́ бы́ли скла́дені. Ай вы́сыпав та́м, та ка́же - «Но́, бери́ собі та йди́ со діло́м сво́йим».

[Рассказывал старый Костюк, как его дядя - это давно было - шел из леса, ну ходил по орехи. Осенью у нас всегда, когда уродятся орехи, мы ходим по орехи. И шел, а на пути стоит горка орехов. Такая горка, что одним $<$ орехом $>$ сверху заканчивается. А он эти орехи забрал в сумку и пошел домой. И вот ночью слышит - под окном кто-то кричит: «Откуда ты эти орехи взял, там их и положи, а если нет, - говорит, - то так тебя буду гонять, как Марию Катунову». Это у нас тут были, так их звали, и нехорошо было женщине. Ну и так он ему сказал, рассказал, что так будет гонять, как ту. А этот утром встал, и прекрасно эти орехи, так у него в сумке и были отдельно, и понес на то место, и там уже он их не 
складывал, потому что он никогда бы их так не сложил, как они были сложены. А высыпал там и говорит: «Ну, бери себе и иди со ділом своим»] (КА, аудиозапись Е.В. Степановой (Лесиной), 1990 г.).

Но пак шчо́ вам росказа́ти про водяника́, я́ тй́лько-м чу́ла, шчо прика́зовали жо́ны, ош я́к вечӥрни́ці бы́ли, та дівкы́ пря́ли. Но́, та зайшо́в.. ишли́ хло́пці все́ на вечӥрни́ці, айбо тогды́ яко́йсь зайшо́в такь́й леги́нь, шо вны́ його́ ни упознаву́ть. И.. а такы́й высо́кый, шчо.. но.. май высо́кый, ги дру́гі лю́де. [...] А ба́ба там бы́ла така́ стара́, та моло[ди́] ся не зна́ли, шчо роби́ти. А ба́ба взя́ла кло́ча, тако́го при́дива фа́йного, та ка́же: «Но́, прийшо́в ты, леги́ню, до на́с, та бу́деме сука́ти мотузо́к. Бо тре́ба ми мо́туза». Та дала́ йому́ у ру́кы, обы́ держа́в. Она су́че, та все́ йому́ ка́же - «Поступа́й ся да́ле, поступа́й ся да́ле». Та́к шчо она́ пома́лы та́к су́чучи, тай поступа́в ся овй́н во́н, во́н, во́н, а она́ ка́ - «Шче́ да́ле, шче́ да́ле!», до́кӥ ни запе́лла две́рі. А як запе́лла две́рі «Но, - ка́же, - иди́ со діло́м сво́им». И вши́тко. - Водяни́к, та́к шо то́ тако́е ся уро́дить. Уро́дить ся, - то́т, шо ся уто́пить, овйн така́ душа́, ги дру́гі, та то́т ни хо́дить. Ай хо́дить тко неправы́й.

[Ну что вам рассказать про водяника, я только слышала, что рассказывали женщины, что когда были вечерки, девушки пряли. Ну и зашел... ходили хлопцы всё время на вечерки, но тогда какой-то зашел такой парень, что они его не узнают. И... а такой высокий, что... выше, чем другие мужчины. А бабушка там была такая старая, и молодые не знали, что делать. А баба взяла пряжу, такой пряжи хорошей, и говорит: «Ну, пришел ты, парень, к нам, так будем сучить веревочку. Потому что мне нужна веревка». И дала ему в руки, чтобы держал. Она сучит, и всё время ему говорит: «Отступи подальше, отступи подальше». Так что она потихоньку так сучила, и отступал он дальше, наружу, а она говорит: «Еще дальше, еще дальше!», - пока не закрыла дверь. А как закрыла дверь - «Ну, - говорит, - иди со ділом своим». И всё. - Водяник, это он таким родится. Родится, - тот, что утопится, он душа такая же, как и другие, так тот не ходит. А ходит тот, кто неправый] (КА, аудиозапись Е.В. Степановой (Лесиной), 1990 г.).

\section{с. Черный Поток:}

Жабы и жоны суть. Такі́ суть ра́з. Тото́ тако́є ни мо́ж би́ти, на́й собі йде́ сво́йими суділа́ми. (А какие жоны?) Но́, хоть ко́трі, таку́ Бо́г да́сьть шо у жа́бу ся учи́нить.

[Лягушки и женщины бывают. Встречаются такие. Это такое нельзя убивать, най собі йде свойими суділа́ми. (А какие женщины?) Ну, любые, такую Бог даст, что превращается в лягушку] (КА, аудиозапись М.Н. Толстой, 1993 г.) 


\section{с. Синевир 6 :}

Нó, зна́єте, бы́ла одна́ ді́вка, но́, і всі́ йі ду́же люби́ли, ду́же фа́йна бы́ла. И.. но та у селі́, ду́же за нив, ду́же хло́пці всі́ бі́галі. И ра́с она́ ка́же - «Ма́мо, ка́же, мене́, ка́е, та.. я́, ка́е, не мо́жу, ка́е, вӥдда́ти ся, ка́же, бо я́, ка́же, ни така́ люди́на, як дру́гі. Я́, ка́же, му́шу умера́ти». А ма́ти ду́же рева́ла, бо лиш одна́ ді́вка ся́ у не́йі бы́ла, а два́ хло́пці шче́. И вна́ ма́тери всьо́ росказа́ла, а ма́ти йӥй ка́е - «Кой ты́ така́, та Бо́г ис тобо́в, ка́е, иди́. Ис сво́йими су... суділіла́ми. Я́к-ись ся уро́дила, ка́е, та́к иди́». И да́ле вна́, як уме́лла, и вна́ ходи́ла по ть́х... по кафе́, всю́ды та́к, и зволо́човала хло́пцӥ. И все́ находи́ли хло́пцӥ ме́ртвых. Розумі́єте, и нитко́ ни могли́, ни мілі́ція, - то́ вже при... при ру́ськӥй вла́сти се сяко́є бы́ло. Нитко́ ни могли́ дізна́ти ся, до чóго сесе́ $́$. $<$ В дальнейшем одного парня она случайно не успела до первых петухов погубить, и тот дознался о ней у ее родителей; раскопали ее могилу, нашли ее как живую, заклинали и обсыпали освященным маком.>

[Ну, знаете, была одна девушка, ну, и все ее очень любили, она была очень красивая. И... ну и в селе очень за ней, очень все хлопцы бегали. И однажды она говорит: «Мама, говорит, меня... я, говорит, не могу, говорит, выйти замуж, говорит, потому что я, говорит, не такой человек, как другие. Я, говорит, должна умереть». А мать очень плакала, потому что у нее только одна дочка была, а еще два сына. И она матери всё рассказала, а мать ей говорит - «Если ты такая, то Бог с тобой, - говорит, - иди. Ис свойими су... суділілами. Какой ты родилась, - говорит, - так иди». И потом она, когда умерла, и она ходила по этим... кафе, всюду так, и завлекала хлопцев. И все время находили хлопцев мертвых. Понимаете, и никто не мог, ни милиция - это уже при русской власти это такое было. Никто не мог дознаться, что это такое] (аудиозапись С.П. Бушкевич, 1993 г.).

Церковнославянское происхождение этой формулы, как кажется, не вызывает сомнений. Можно предположить, что ее источником является словосочетание «по делом своим» (И даде море мертвеизы своя, и смерть и ад даста своя мертвецьв: и суд прияша по делом своим Откр. 20:13), которое не могло быть опознано как дат. п. мн. ч. из-за чуждой флексии, а также потому, что предлог по в украинско-белорусском диалектном ареале управляет предложным падежом, а не дательным. Выше варианты формулы перечислены в порядке затемнения ее 
смысла. В с. Керецки в выражении иди́ со діло́м сво́им существительное было опознано как форма тв. п. ед. ч., а предлог заменен на «с» в церковнославянской форме; чуждым диалекту является и ударение существительного: слово ді́ло (а. п. a) в тв. ед. в нормальном случае имеет ударение ділом. В с. Черный Поток в выражении най собi йде cвоіми суділа́ми предлог превратился в приставку су- (этому способствовал, видимо, фонетический закон повышения средних гласных перед мягкими согласными, см. Толстая 2009); кроме того, не исключено, что корень мог быть переосмыслен как діл ('гора-водораздел'), и с утратой предлога словосочетание могло получить пространственное значение. Возможно также, что сочетание с предлогом было переосмыслено как существительное с корнем «суд», «судить». Наконец, у молодой информантки из с. Синевир внутренняя форма этого выражения оказалась окончательно затемненной, в существительном появился лишний слог. В принципе формулировка иди́ со діло́м сво́им могла бы быть исходной для остальных вариантов, но о конкретных путях ее преобразований остается лишь гадать.

Нужно отметить, что у слова дело в народной культуре Карпат регулярно отмечаются мифологические коннотации, в частности, у выражения мати діло: ср. в гуцульских заговорах: «аби до мене нїхто дїла не мав, так як я ходжу від рана до схід сонця а мене нїхто не пізнав» (Шухевич 4: 259-260, Жабє, Бервінкова); Щезни, пропади! Ти до сего тїла не маєш дїла! (Шухевич 5: 249, Шешори); «аби се счезло, пропало йик піна на водї, йик роса на траві, аби воно не мало дїла до білого тїла, до жовтої кости, до черленої крови, абе се не мало дїла тїло влеєти, молодість відбирати, володи пускати <..>» (Шухевич 5: 220, Жабє). В быличке из с. Торунь Межгорского р-на Закарпатья это словосочетание встречается в ряду отгонных формул: «А лю́де ся боя́т, та закрыва́ют, та ка́жут - цура́ха му, осцина́ бы му, няй иде́ ві́тсї на пусьці́ пусты́нї! Шчо́ він ту́йкы на́м дй́ло ма́є? Шчó він ту́йкы нам хо́че роби́ти? А го́йкают лю́де» [А люди боятся, и запираются, и говорят - иураха бы ему, осцина бы ему, пусть идет отсюда в пустые пустыни! Что он здесь нам дїло мá $\epsilon$ ? Что он здесь нам хочет делать? Кричат люди] (Николаев, Толстая 2001: 228). В «этнографическом» романе П. Шекерика-Доникова, уроженца гуцульского села Головы, поганым делом в заговоре называется нечистая сила и болезни: «“< ..> Ск усі болі поздоймали, У стоящу судину поссипали. Поссипали тай заткали, На стоящу гору видослали. На стоящій горі пресподну єму копали И то погане діло у ту єму пустили, Й там загребли, забили, Заклєли навіки віков. Амінь". <..> Здував ничісту силу, спльовуючі у лівий бік: “Ху, тфу, зчєзни, ничіста сило. Ху, тфу, пропади погане діло. Ху, тфу, ни май моци та путері до мене, иршєного, пороженого Ивана”» [«Когда все болезни поснимали, 
в стоячую посудину поссыпали. Поссыпали и заткнули, на стоячую гору отослали. На стоячей горе преисподнюю яму копали и это поганое дело в ту яму пустили, и там закопали, забили, закляли на веки веков. Аминь». <..> Сдувал нечистую силу, сплевывая в левую сторону: «Ху, тфу, исчезни, нечистая сила. Ху, тфу, пропади, поганое дело. Ху, тфу, не имей силы и способности ко мне, крещеному, рожденному Ивану»] (Шекерик 2008: 29-30).

В 2019 г. мне удалось побывать в Синевире и расспросить о выражении «со ділами своими» у Анны Степановны Цимбота, замечательной информантки и знатока синевирского диалекта и народной культуры. Она рассказала о немифологическом употреблении этой формулы (близком по значению к «Бог ему судья»): так говорят об умерших (причем с осуждением); можно так сказать и о ведьме. Таким образом, покойники и нечистая сила по синевирским материалам объединяются как представители потустороннего мира (вспомним, что и в быличке о дочке-двоедушнице мать говорит ей эти слова перед ее смертью):

Со діла́ми сво́йими. Пак тото́ за ме́ртвого ка́жут! Пак уме́р... уме́р та со діла́ми сво́йими, шчо́ собі́ нароби́в, та с ти́м пӥде́. Шчо́ за житя́ нароби́в, ис ты́м собі́ пӥде́, со діла́ми сво́йими. (А коли тото мож казати?) Пак тото́ про́сто та́к.. пак хоть ко́ли мож каза́ти. Хоть ко́ли, не́ лиш у якы́сь ча́с, вать... та́к, со діла́ми сво́йими, на́й собі́ йде́. [...] Шо́сь говоря́т, изы́йдут ся на по́хорон, че́лядь, та шо́сь говоря́т, но, пак та́ ге́, ка́жут, но́, се́сь сякы́й быв, вать такы́й быв, вать.. вать за ко́гось ка́жут фа́йно. А за ко́гось ка́жут нефа́йно, тко́сь кому́сь шчо́сь недо́бре зроби́в. Пак ка́жут, ка́ждоє со діла́ми сво́йими най иде́. Тко́ роби́в до́броє, най иде́ 3 до́брым, тко́ недо́бре, най иде́ с такы́м, ка́ждоє со діла́ми сво́йими. У на́с ка́жут, ка́ждоє со діла́ми сво́йими, я́ бим тобі́ та́к каза́ла, шо ка́жда люди́на най иде́ со діла́ми сво́йими. (То лиш як уже умер? За живых так не кажут?) За живы́х нє́, за живы́х не ка́жут. За живы́х лиш ка́жут - Бо́же, яка́ нече́сна, ци нече́сный, ци га́мішноє, ци... ци сяко́є, ци тако́є.. Про ко́го я́к ка́жут, та́к за ньо́го ка́жут, а «со діла́ми сво́йими» - лиш за ме́ртвого. (А ци не мож так казати за якусь босорканю, ци за жабу, вать штось тако́є?) За босорка́ню... пак мо́же и мо́ж и за босорка́ню. (Як шчось думают, шчо шчось нечисте?) Мо́ж.. мо́ж.

[Со ділами сво́йими. Так это о мертвом говорят! Ну умер... умер - и со ділами сво́йими, что себе наделал, с этим пойдет. Что за жизнь наделал, с тем себе пойдет, со ділами сво́йими. (А когда это можно сказать?) Ну это просто так.. когда угодно можно сказать. Когда угодно, не в какое-то определенное время, или... так, со ділами сво́йими, пусть себе идет. <..> Что-то говорят, соберутся на похороны, люди, и что- 
то говорят, ну, и вот, говорят, этот такой был, или сякой был, или.. или о ком-то говорят хорошо. А о ком-то говорят плохо, кто-то комуто что-то нехорошее сделал. Ну и говорят, каждый со ділами сво́йими пусть идет. Кто делал хорошее, пусть идет с хорошим, кто плохое, пусть идет с таким, каждый со ділами сво́йими. (Это только когда уже умер? О живых так не говорят?) О живых нет, о живых не говорят. О живых говорят только - боже, какая нечестная, или нечестный, или лицемерный, или такой, или сякой. Про кого как говорят, так о нем и говорят, а «со ділами сво́йими» - только о мертвом. (А можно так сказать о какой-нибудь ведьме, или жабе, или о чем-то таком?) О ведьме... наверно, можно и о ведьме. (Если думают, что что-то нечистое?) Можно... можно.]

Приведенный материал проливает свет на механизмы взаимодействия книжной и народной традиции и народного (диалектного) и церковнославянского языка и способы включения книжных элементов (молитвенных формул) в контекст народной мифологической традиции.

\section{Сокращения}

Беньковский 1896 - Беньковский И. Смерть, погребение и загробная жизнь. Киев, 1896.

Виноградова 2016 - Виноградова Л.Н. Мифологический аспект славянской народной традиции. М., 2016.

Виноградова 2019 - Виноградова Л.Н. Особая категория мифологических персонажей: «души-покутники» // Живая старина. 2019. № 2. С. 19-21.

Гнатюк ЕЗ 15 - Гнатюк В. Знадоби до галицько-руської демонольогії // Етнографічний збірник. Львів, 1904. Т. 15.

Гнатюк Е3 31-32 - Гнатюк B. Похоронні звичаї й обряди // Етнографічний збірник. Львів, 1912. Т. 31-32. С. 203-424.

Гнатюк Е3 33 - Гнатюк В. Знадоби до української демонольогії. Т. 2, вип. 1 // Етнографічний збірник. Львів, 1912. Т. 33.

Гнатюк Е3 34 - Гнатюк B. Знадоби до української демонольогії. Т. 2, вип. 2 // Етнографічний збірник. Львів, 1912. Т. 34.

ГПЗН - Говірки південно-західного наріччя української мови / Уп. Н.М. Глібчук. Львів, 2000.

Ђорђевић 1953 - Ђорђевић T.P. Вампир и друга бића у нашем народном веровању и предању // Српски етнографски зборник. Књ. 66. Београд, 1953.

КА - Карпатский архив Института славяноведения РАН (материалы экспедиций). 
НДП 2 - Народная демонология Полесья (Публикации текстов в записях 80-90-х годов XX века). М., 2012. Т. 2. Демонологизация умерших людей / Сост. Л.Н. Виноградова, Е.Е. Левкиевская.

Николаев, Толстая 2001 - Николаев С.Л., Толстая М.Н. Словарь карпатоукраинского торуньского говора с грамматическим очерком и образцами текстов. М., 2001.

Панькевич 2008 - Панькевич И. Українські говори Підкарпатської Руси і сумежних областей. Прага, 1938.

Петровцій 2014 - Петровиій Иван. Бумбурішкы. Русинськоє читаня. Осӥй; Ужгород, 2014 (https://petrovtsiy.jimdo.com/проза/бумбурішкы/).

Толстая 1999 - Толстая М.Н. Несколько текстов из села Синевир // Славянские этюды. Сборник к юбилею С.М. Толстой. М., 1999. С. 477-490.

Толстая 2001 - Толстая М.Н. Из материалов карпатских экспедиций // Восточнославянский этнолингвистический сборник. М., 2001. С. 477-495.

Толстая 2009 - Толстая М.Н. Позиции регрессивной аккомодации и гармонии гласных в закарпатском говоре с. Синевир // Исследования по славянской диалектологии. М., 2009. [Вып.] 14. Фонетический аспект изучения славянских диалектов. С. 115-143.

УЗГТ - Українські закарпатські говірки. Тексти / УП. О. Миголинець, О. Пискач. Ужгород, 2004.

Франко 1978 - Франко I. Як русин товкся по тім світі // Франко I. Зібрання творів: у 50 т. Т. 1-25. Художні твори. Т.16. Повісті та оповідання (1882-1887). Київ, 1978.

Шекерик 2008 - Шекерик-Доників П. Дідо Иванчік. Косів, 2008.

Шухевич 4, 5 - Шухевич В. Гуцульщина. Львів, 1904. Т. 4; 1908. Т. 5.

Чуб.ТЭСЭ 1 - Труды этнографическо-статистической экспедиции в Западно-Русский край, снаряженной Императорским Русским географическим обществом: Юго-Западный отдел. Материалы и исследования, собранные П.П. Чубинским. СПб., 1872. Т. 1.

Черленяк 2018 - Черленяк (Керечанин) I. Апотропеїчні заходи для живих та магічні дії, пов'язані зі спорядженням мерця в українців Закарпаття // Народознавчі зошити. 2018. № 3 (141) С. 662-670.

Fed.LB 1 -Federowski M. Lud Białoruski na Rusi Litewskiej. Materiały do etnografii słowiańskiej zgromadzone w latach 1877-1905. Kraków, 1897. T. 1: Wiara, wierzenia i przesądy ludu z okolic Wołkowyska, Słonima, Lidy i Sokółki.

Pełka 1987 - Pełka L. J. Polska demonologia ludowa. Warszawa, 1987.

WSJP - Wielki słownik języka polskiego. PAN (https://wsjp.pl/index. php?id_hasla=30136). 